\title{
TINJAUAN PELAKSANAAN PEMELIHARAAN DOKUMEN REKAM MEDIS DI RUANG FILING RUMAH SAKIT JIWA Prof.Dr.MUHAMMAD ILDREM MEDAN TAHUN 2018
}

\author{
1. Tri Widya Sandika; ${ }^{2 \cdot}$ Ernianita \\ 1. Dosen STIKes Imelda, Jalan Bilal Nomor 52 Medan; ${ }^{2}$ Alumni APIKES Imelda
}

E-mail: ${ }^{1 .}$ Triwidyasandika.tri306@gmail.com

\begin{abstract}
ABSTRAK
Rekam medis merupakan berkas yang berisi catatan dan dokumen mengenai identitas pasien, hasil pemeriksaan, pengobatan, tindakan dan pelayanan lainnya yang telah diberikan kepada pasien. Sistem pengelolaan rekam medis terdiri dari beberapa subsistem, yaitu dimulai dari tempat penerimaan pasien (membuat atau menyiapkan berkas rekam medis), dilanjutkan dengan assembling, coding, indexing, dan filling. Dibagian filling penyimpanan dan pengembalian kembali rekam medis dilakukan, penyimpanan berkas rekam medis bertujuan untuk mempermudah dan mempercepat ditemukan kembali berkas rekam medis yang disimpan dalam rak filing, mudah mengambil dari tempat penyimpanan, mudah pengambilannya, melindungi berkas rekam medis dari bahaya keruakan fisik, kimiawi dan biologi. Tujuan penelitian adalah untuk melihat pelaksanaan pemeliharaan dokumen rekam medis di Rumah Sakit Jiwa Prof.Dr.Muhammad Ildrem Medan Tahun 2018.Jenis penelitian ini menggunakan metode deskriptif, yaitu menggambarkan pelaksanaan pemeliharaan dokumen rekam medis di ruang filing tahun 2018. Dari hasil penelitian Novia Wijiastuti (2014) tentang Pemeliharaan Dokumen Rekam Medis di Ruang Rawat Inap RSUD Sunan Klijaga masih ada aspek fisik bahwa folder yang rusak masih belum diganti yang baru. Berdasarkan hasil penelitian di Rumah Sakit Jiwa Prof.Dr.Muhammad Ildrem Medan Tahun 2018 jika dilihat dari aspek fisik terdapat dokumen rekam medis yang sudah rusak seperti formulir robek sehingga identitas dan no rekam medis pasien tidak terbaca serta keamanan ruang penyimpanan yang kurang baik.
\end{abstract}

Kata Kunci : Pemeliharaan, Dokumen Rekam Medis, Filing

\section{PENDAHULUAN}

Menurut WHO (World Health Organization) tahun 2010, rumah sakit adalah bagian integral dari suatu organisasi sosial dan kesehatan dengan fungsi menyediakan pelayanan paripurna (komprehensip), penyembuhan sakit (kuratif) dan pencegahan penyakit (preventif) kepada masyarakat.

Menurut AHIMA (American Health Information Management Association ) tahun 2008, membuat pengaturan lebih lanjut dalam Statement on Preservation of Patient Medical Record in Health Care Institution. Dalam aturan tersebut dikatakan bahwa pada kasus biasa berkas Rekam Medis disimpan sampai 10 tahun terhitung dari saat pasien terakhir berobat. Sedangkan pada kasus yang diperkarakan di pengadilan, penyimpanan berkas rekam medisnya lebih lama lagi yaitu 10 tahun kemudian terhitung sejak perkara terakhinya selesai. "Berkas yang telah habis masa penyimpannya dapat dimusnahkan, kecuali jika ada halangan oleh peraturan lain. Di negara bagian Califonnia Amerika Serikat, penyimpanan rekam medis adalah 7 tahun sejak terakhir kali pasien berobat. Untuk pasien anak-anak, penyimpanan berkasnya bahkan sampai yang bersangkutan berusia 21 tahun, dan kalau perlu bahkan sampai 28 tahun. Di Pensylvania masa penyimpanannya lebih lama yaitu sampai 15 tahun, bahkan di negara Israel sampai 100 tahun. Dalam rangka penghematan ruangan penyimpanan, 
ada beberapa negara yang membolehkan berkas yang berusia lebih dari 3 tahun dari saat terakhir pasien berobat, dialihkan menjadi berkas dalam microfilm.

Rekam medis merupakan berkas yang berisi catatan dan dokumen mengenai identitas pasien, hasil pemeriksaan, pengobatan, tindakan dan pelayanan lainnya yang telah diberikan kepada pasien. Penyelenggaraan rekam medis merupakan proses kegiatan yang dimulai pada saat diterimanya pasien di rumah sakit, diteruskan kegiatan pencatatan data medis pasien selama pasien itu mendapatkan pelayanan medis di rumah sakit, dan dilanjutkan dengan penanganan berkas rekam medis yang meliputi penyelenggaraan penyimpanan untuk melayani permintaan dari pasien atau untuk keperluan lainnya (Permenkes No. 269/Menkes/Per/III/2008 pasal 1).

Menurut Permenkes No 55 Tahun 2013

Tentang Penyelenggaraan Pekerjaan Perekam Medis Pasal 1 yaitu Manajemen Pelayanan Rekam Medis dan Informasi Kesehatan adalah kegiatan menjaga, memelihara dan melayani rekam medis baik secara manual maupun elektronik sampai menyajikan informasi kesehatan di rumah sakit, praktik dokter klinik, asuransi kesehatan, fasilitas pelayanan kesehatan dan lainnya yang menyelenggarakan pelayanan kesehatan dan menjaga rekaman.

Fungsi dokumen rekam medis bagi rumah sakit adalah sebagai sumber ingatan dan sebagai sumber informasi dalam rangka melaksanakan perencanaan, penganalisaan, pengambilan keputusan, penilaian dan dipertanggung jawabkan dengan sebaikbaiknya, untuk mendukung terciptanya keberhasilan penyimpanan, pengamatan, dan pemeliharaan dokumen rekam medis diperlukan adanya ketentuan pokok kearsipan yaitu tempat, sarana prasarana, pemeliharaan dokumen dari bahaya dan kerusakan (Savitri Citra Budi, 2011).

Sistem pengelolaan rekam medis terdiri dari beberapa subsistem, yaitu dimulai dari tempat penerimaan pasien (membuat atau menyiapkan berkas rekam medis), dilanjutkan dengan assembling, coding, indexing, dan filling. Dibagian filling penyimpanan dan pengembalian kembali rekam medis dilakukan, penyimpanan berkas rekam medis bertujuan untuk mempermudah dan mempercepat ditemukan kembali berkas rekam medis yang disimpan dalam rak filing, mudah mengambil dari tempat penyimpanan, mudah pengambilannya, melindungi berkas rekam medis dari bahaya keruakan fisik, kimiawi dan biologi ( Savitri Citra Budi, 2011).

Menurut Rustiyanto dan Rahayu (2011), filing merupakan kegiatan menyimpan, penataan, atau penyimpanan berkas rekam medis untuk mempermudah pengambilan kembali (Retrieval). Salah satu unit rekam medis untuk menunjang pelayanan rekam medis adalah ruang penyimpanan di mana berkas rekam medis baik rawat jalan, rawat inap, maupun gawat darurat disimpan. Karena rekam medis bersifat rahasia dan mempunyai aspek hukum maka keamanan fisik menjadi tanggung jawab rumah sakit, sedangkan aspek isi dari rekam medis merupakan milik pasien.

Riset menunjukkan bahwa kegiatan menyimpan rekam medis merupakan usaha melindungi rekam medis dari kerusakan fisik dan isi dari rekam medis itu sendiri. Rekam medis harus disimpan dan dirawat dengan baik karena rekam medis merupakan harta benda rumah sakit yang sangat berharga, mengingat pentingnya berkas rekam medis, maka harus disimpan dan dipelihara dengan baik dan benar maka akan mendukung tercapainya tertib administrasi.

Dari hasil penelitian Nadya Hairani (2012) tentang Upaya Pencegahan Bahaya Kerusakan Dan Pemeliharaan Rekam Medis Di Rumah Sakit Umum Daerah Tarakan Jakarta Tahun 2012, Bahwa pemeliharaan rekam medis perlu ditunjang dengan system keamanan dan pemeliharaan gedung yang baik untuk mengantisipasi berbagai hal-hal yang tidak di inginkan, seperti pencurian dokumen, kebocoran, kebakaran, dan lainlain. Untuk itu dibutuhkan suatu kebijakan tertulis yang dapat mengelola dan merawat dokumen rekam medis tersebut sehingga dapat bertahan lama dan dipelihara dengan baik dan benar. 
Dari hasil penelitian Novia Wijiastuti (2014) tentang Tinjauan Pelaksanaan Pemeliharaan Dokumen Rekam Medis Di Ruang Filing Rawat Inap RSUD Sunan Kalijaga Demak Tahun 2014, untuk pelaksanaan pemeliharaan di rumah sakit tersebut belum sesuai dengan teori, dapat dilihat dari aspek fisik bahwa folder yang telah rusak belum diganti dengan yang baru, sedangkan menurut teori bila terdapat folder dokumen rekam medis yang rusak sebaiknya dig anti dengan yang baru, agar mudah dibaca serta untuk menjaga keamanan dan kerahasiaan dokumen rekam medis di Rumah Sakit RSUD Sunan Kalijaga Demak.

Sedangkan hasil penelitian Ni Putu Tika Pramesti (2014) tentang Pemeliharaan Rekam Medis Inaktif Pasien Jiwa Di RSJ Grhasia DIY untuk Pemeliharaan dokumen rekam medis inaktif masih ditemukan beberapa kendala antara lain belum maksimalnya pemeliharaan rekam medis karena belum ada Standart Operasional Prosedur yang mengatur tentang pemeliharaan rekam medis, maka pelaksanaan pemeliharaan yang dilakukan masih dengan cara yang sederhana, belum memiliki job description pemeliharaan dokumen rekam medis, kurangnya ruang dan rak penyimpanan rekam medis inaktif, belum memiliki penanggung jawab, suhu ruangan tidak pernah dipantau dan tidak memiliki alat pemadam api ringan.

Berdasarkan survey awal di Rumah Sakit Jiwa Prof.Dr.Muhammad Ildrem Medan Tahun 2018 jika dilihat dari aspek fisik terdapat dokumen rekam medis yang sudah rusak seperti formulir robek sehingga identitas dan no rekam medis pasien tidak terbaca serta keamanan ruang penyimpanan yang kurang baik.

Berdasarkan latar belakang diatas penulis tertarik untuk melakukan penelitian dengan judul "Tinjauan Pelaksanaan Pemeliharaan Dokumen Rekam Medis di Ruang Filing Rumah Sakit Jiwa Prof.Dr.Muhammad Ildrem Medan Tahun 2018".

\section{Perumusan Masalah}

Berdasarkan latar belakang diatas, maka penulis merumuskan masalah penelitian ini yaitu:Bagaimana pelaksanaan pemeliharaan dokumen rekam medis di Rumah Sakit Jiwa Prof.Dr.Muhammad Ildrem Medan.

\section{Tujuan Penelitian}

Adapun tujuan dari penelitian ini adalah mendeskripsikan pelaksanaan pemeliharaan dokumen rekam medis diruang filing Rumah Sakit Jiwa Prof.Dr.Muhammad Ildrem Medan Tahun 2018.

\section{Manfaat Penelitian}

1. Bagi Rumah Sakit

Dengan adanya pelaksanaan penelitian ini diharapkan dapat membantu dalam pengambilan keputusan bagi rumah sakit untuk perencanaan pelayanan kesehatan di masa yang akan datang dan bisa sebagai masukan bagi rumah sakit untuk meningkatkan kualitas pelayanannya kepada masyarakat.

2. Petugas Rekam Medis

Untuk menambah wawasan/pengetahuan bagaimana pelaksanaan pendistribusian berkas rekam medis rawat jalan yang standar prosedur operasional rekam medis.

\section{METODE}

\section{Jenis Penelitian}

Metode penelitian deskriptif adalah suatu metode penelitian yang dilakukan dengan tujuan untuk membuat gambaran atau deskriptif tentang suatu keadaan secara objektif.

\section{Tempat Penelitian}

Penelitan dilakukan di Rumah Sakit JiwaProf Dr. Ildrem.

\section{Populasi}

Populasi penelitian ini adalah seluruh petugas rekam medis yang ada di Rumah Sakit Jiwa Prof.Dr.Muhammad Ildrem Medan yaitu berjumlah 2 orang.

\section{Sampel dan Teknik Sampling}

Dengan menggunakan tehnik total sampel seluruh petugas rekam medis di 
Rumah Sakit Jiwa Prof.Dr.Muhammad Ildrem Medan yaitu berjumlah 2 orang.

\section{Instrumen Penelitian}

Instrumen penelitian yang digunakan dalam penelitian ini yaitu pedoman wawancara dan direkam menggunakan alat perekam audio serta lembar check list untuk observasi.

\section{Sumber Data}

Adapun sumber data yang digunakan yaitu:

1. Data primer

Sumber data primer diperoleh melalui wawancara dan pengamatan langsung dilapangan. Sumber data primer merupakan data yang diambil langsung oleh peneliti kepada sumbernya tanpa ada perantara dengan cara menggali sumber secara langsung melalui responden. Sumber data primer dalam penelitian ini kepala unit rekam medis dan petugas penyimpanan di Rumah Sakit Jiwa Prof.Dr.Muhammad Ildrem Medan Tahun 2018.

2. Data sekunder adalah data yang sudah ada yaitu Sumber Data sekunder diperoleh melalui Data dokumentasi dan studi kepustakaan dengan bantuan media cetak dan media internet secara catatan lapangan. Sumber data sekunder merupakan sumber data tidak langsung yang mampu memberikan data tambahan serta penguatan terhadap data peneliti.

\section{Cara Pengumpulan Data}

Pengumpulan data dilakukan dengan wawancara dan observasi.

\section{HASIL}

Berdasarkan hasil observasi yang peneliti lakukan di Rumah Sakit Jiwa Prof.Dr.Muhammad Ildrem Medan pada bulan Mei-Juli, diiketahui bahwa untuk ruang penyimpanan terletak dilantai 1 dan dekat dengan loket pendaftaran, masih terdapat formulir rekam medis yang rusak dan tidak diganti dengan yang baru, dalam ruang penyimpanan masih terdapat beberapa meja petugas yang dekat dengan rak penyimpanan sehingga dapat menyulitkan petugas dalam pengambilan dan pengembalian dokumen rekam medis ke rak penyimpanan. Untuk rak penyimpanan sudah menggunakan lemari roll opack. Untuk sistem pengolah dokumen rekam medis terdapat satu petugas pendaftaran, satu petugas indexing, dan satu petugas penyimpanan, namun karena kurangnya jumlah SDM maka tugas pengolahan rekam medis lainnya dilakukan dengan cara kerjasama.

Sistem penyimpanan yang dilakukan menggunakan sistem sentralisasi, dan menggunakan sistem penomoran langsung, untuk proses peminjaman dokumen rekam medis sudah menggunakan buku ekspedisi, hal ini dilakukan agar petugas penyimpanan dapat mengetahui siapa yang meminjam serta dimana keberadaan rekam medis itu sendiri dan untuk keperluan apa rekam medis tersebut dipinjam.

Berdasarkan wawancara mendalam yang dilakukan peneliti terhadap informan mengenai Tinjauan Pelaksanaan Pemeliharaan Dokumen Rekam Medis Di Ruang Filing Rumah Sakit Jiwa Prof.Dr.Muhammad Ildrem Medan Tahun 2018, diperoleh hasil yang hampir serupa antar jawaban yang satu dengan jawaban yang lainnya dari masing - masing informan.

Seperti hasil wawancara mendalam tentang apakah luas ruang penyimpanan rekam medis sudah memadai di Rumah Sakit Jiwa Prof.Dr.Muhammad Ildrem Medan, yang dilakukan dengan responden 01 dan dilakukan dimeja kerjanya sebagai berikut :

" Seperti yang kita lihat kondisi yang sekarang menurut saya ruangan ini kurang luas".

Kemudian peneliti lanjut bertanya tentang apakah tata letak fasilitas yang ada diruang penyimpanan rekam medis sudah layak? Lalu responden 01 menjawab sebagai berikut : "Belum, karena masih terdapat beberapa meja petugas yang terletak dekat dengan rak penyimpanan".

Lebih lanjut peneliti menanyakan tentang apakah sudah ada tugas dan 
tanggung jawab bagi petugas penyimpanan ? dan beliau menjawab : "Sudah ada alur beserta ketentuan bagi petugas rekam medis disini, namun karena kurangnya SDM maka harus dilakukan dengan cara kerja sama agar tetap terlaksana dengan baik".

Ketika peneliti menanyakkan tentang bagaimana cara petugas dalam menjaga keamana dokumen rekam medis? lalu responden 01 pun menjawab seperti ini : “ yah, ketika berkas rekam medis keluar dari rak penyimpanan untuk pelayanan kesehatan maka rekam medis itu harus kembali dan disimpan dengan baik dan benar dalam rak penyimpanan".

Lebih lanjut peneliti menanyakkan kepada responden 01, lalu bagaimana untuk menjaga kerahasiaannya? Responden langsung menjawab : " Ketika berkas rekam medis keluar dari rak penyimpanan karna untuk keperluan peminjaman makan kami mengguanakan buku ekspedisi untuk mencatat siapa yang meminjam dan untuk apa dokumen tersebut digunakan".

Kemudian peneliti bertanya tentang apakah pernah kehilang dokumen rekam medis? Jika pernah, apa penyebabnya? Responden 02 menjawab sebagai berikut : "Pernah, penyebabnya itu biasanya karena salah letak atau kadang dokumen tersebut dibawa pulang oleh salah seorang pasien".

Lalu peneliti lanjut menanyakkan tentang adakah alat pemadam kebakaran api ringan (APAR) didalam ruang penyimpanan? Lalu responden 02 menjawab : " ada itu nempel hehehe".

Lalu responden 01 menyimpulkan "karna ini ruangan rekam medis banyak kertas atau bahan yang mudah terbakar jadi pihak rumah sakit sudah menyediakan alatalat seperti itu".

Lebih dalam peneliti bertanya untuk sistem penyimpanan yang digunakan dirumah Sakit Jiwa Prof.Dr.Muhammad Ildrem sistem penyimpanan yang bagaimana? Responden 02 pun menjawab : "Kami disini nmenggunakan sistem penyimpanan sentralisasi dimana berkas rekam medis rawat jalan dan rawat inap dijadikan satu dalam satu map".

Kemudian informasi lainnya disampaikan oleh responden 02 saat ditanyai mengenai apakah ada larangan masuk bagi selain petugas rekam medis yang masuk keruang penyimpanan? Responden menjelaskan bahwa : "Ada, Namun terkadang masih ada juga petugas lain yang masuk karna kepentingan lain ".

Saat perihal ditanyai mengenai Jika jam kerja sudah selesai, apakah ruang penyimpanan terkunci pak? apabila dikunci, kuncinya siapa yang bawa atau diletakkan dimana pak? Jika dipegang petugas? Dan petugas datang terlambat, apakah tidak menghambat pelayanan? Responden menjawab : "Dibawa oleh 1 orang petugas, kami disini sudah ada ketentuan masuk jam kerja jadi harus datang tepat waktu agar proses pelayan tetap berjalan baik"

\section{PEMBAHASAN}

Berdasarkan hasil penelitian tentang pelaksanaan pemeliharaan dokumen rekam medis di Rumah Sakit Prof.Dr.Muhammad Ildrem Medan menunjukkan bahwa untuk prosedur tetap diruang filling sebagian besar sudah sesuai dengan teori, tapi masih ada yang belum sesuai dengan teori yaitu : terdapat beberapa folder yang rusak dan tidak diganti dengan yang baru padahal menurut teori sebaiknya diganti dengan yang baru agar mudah terbaca dan menggunakan map folder yang lebih tebal agar dokumen rekam medis tidak mudah rusak. Pengelolaan ruang penyimpanan yang kurang baik dikarenakan masih terdapat beberapa meja petugas rekam medis yang berada diruang penyimpanan yang dapat menggangu petugas pada saat melakukan proses penyimpanan, suhu ruang yang terdapat didalam ruang penyimpanan kurang terkontrol, namun untuk pencahayaan nya sudah cukup karna terdapat ventilasi yang sudah memadai, sedangkan kelembaban suatu ruangan penyimpanan berdasarkan teori sekitar $50 \%$ sampai $65 \%$ dan suhu udara berkisar antara $18.8^{\circ} \mathrm{C}$ sampai $24,24^{\circ} \mathrm{C}$ apabila suhu kurang dari normal, maka dalam waktu relatif singkat arsip-arsip akan rusak dan belum adanya alat pengukur suhu padahal ruang penyimpanan rekam medis sangat membantu dalam memelihara berkas rekam medis. 
Sistem pengelohan rekam medis di Rumah Sakit Jiwa Prof.Dr.Muhammad Ildrem Medan Tahun 2018 belum sepenuhnya dilakukan sesuai dengan teori seperti untuk proses assembling petugas masih harus melakukannya dengan merangkap pekerjaan karna kurangnya sumber daya manusia, seharusnya menurut teori kegiatan assembling perlu dilakukan dengan baik karna dalam proses ini akan diketahui berkas yang kembali tepat pada waktunya dan terlambat kembali ke unit rekam medis. Pada kegiatan ini petugas juga harus mencatat pada buku register semua berkas yang masuk sesuai tanggal masuk kebagian assembling dan tanggal berapa pasien pulang.

Proses peminjaman dan pengembalian dokumen rekam medis yang keluar dari rak penyimpanan hanya menggunakan buku ekspedisi saja dan belum menggunakan petunjuk keluar (outguide) rekam medis yang keluar atau dipinjam, dengan tidak adanya petunjuk keluar/tracer dirak penyimpanan maka ditemukan kendalakendala dalam sistem penyimpanan diantaranya rekam medis sering terselip, sulitnya pengembalian rekam medis yang keluar dari rak penyimpanan dan memerlukan waktu yang cukup lama untuk disimpan sesuai penjajaran rekam medis yang digunakan. Namun, menurut teori penggunaan petunjuk keluar (outguide) sangat diperlukan agar mudah melacak keberadaan dokumen tersebut tanpa harus mengacak dokumen rekam medis yang lain karna sudah ada petunjuk keluarnya dan memudahkan petugas saat melakukan penyimpanan kembali.

Menjaga kerahasiaan isi dokumen rekam medis di Rumah Sakit Prof.Dr. Muhammad Ildrem belum sepenuhnya menjaga keamanan isi dokumen rekam medis, dikarekan ruang penyimpanan tidak pernah dikunci, sehingga memudahkan orang lain masuk ke dalam ruang penyimpanan, sedangkan menurut teori ruang penyimpanan harus terkunci bila tidak digunakan, agar kerahasiaan isi dokumen rekam medis tetap terjaga dengan baik. masih adanya petugas lain yang masuk keruang penyimpanan padahal menurut teori selain petugas rekam medis dilarang masuk karena dokumen rekam medis bersifat rahasia dan menghindari pencurian dokumen rekam medis. Sedangkan untuk menjaga kerahasiaannya belum juga sepenuhnya dikarenakan masih ada kehilangan dokumen rekam medis dikarenakan dokumen tersebut dibawa pulang oleh pasien, padahal menurut teori berkas rekam medis tidak boleh keluar dari rumah sakit kecuali atas perintah pengadilan.

\section{KESIMPULAN}

Berdasarkan hasil dari penelitian yang berjudul "Pelaksanaan Pemeliharaan Dokumen Rekam Medis Di Ruang Filing Rumah Sakit Jiwa Prof.Dr.Muhammad Ildrem Medan Tahun 2018" yang telah disajikan pada BAB IV dapat disimpulkan bahwa pelaksanaa pemeliharaan dokumen rekam medis dapat dilihat dari aspek fisik bila terdapat folder yang telah rusak belum diganti dengan yang baru, menjaga kerahasiaan isi dokumen rekam medis belum sepenuhnya menjaga kerahasiaan isi dokumen rekam medis karena ruang filing tidak pernah terkunci, petugas filing dalam melayani peminjaman dokumen rekam medis tidak menggunakan tracer sebagai petunjuk keluar dari rak penyimpanan dan hanya menggunakan buku ekspedisi.

\section{SARAN}

Berdasarkan permasalahan diatas, penulis ingin memberikan beberapa saran untuk dijadikan masukkan bagi Rumah Sakit Jiwa Prof.Dr. Muhammad Ildrem Medan mengenai pelaksanaan pemeliharaan dokumen rekam medis diruang filling. Saran-saran tersebut sebagai berikut :

1. Sebaiknya diadakan pelatihan tentang pemeliharaan dokumen rekam medis.

2. Sebaiknya ruang filing rekam medis dalam keadaan terkunci, agar orang lain yang selain petugas tidak bisa masuk ke dalam ruang filing.

3. Sebaiknya menggunakan tracer dirak penyimpanan sebagai petunjuk keluar berkas rekam medis yang keluar dari rak penyimpanan atau dipinjam 


\section{DAFTAR PUSTAKA}

AHIMA. (1975). An Instruction Guide of Organizing Health Records. Chicago: AMRA.

Budi, S. C. (2011). Manajemen Unit Kerja Rekam Medis. Yogyakarta: Quantum Sinergis Media.

Depkes RI. (2006). Pedoman Prosedur dan Penyelenggaraan Rekam Medis Rumah Sakit di Indonesia. Jakarta: Dirjen Yanmed.

Dirjen Yanmed. (2006). Pedoman Penyelenggaraan dan Prosedur Rekam Medis Rumah Sakit di Indonesia. Jakarta : Direktorat Jendral Bina Pelayanan Medik.

Hatta, Gemala R, Editor. Pedoman Manajemen Informasi Kesehatan di Sarana Pelayanan Kesehatan. Jakarta : UI Press. 2010

Menkes RI. (2013). Peraturan Menteri Kesehatan Nomor 55 Tahun 2013 tentang Penyelenggaraan Pekerjaan Perekam Medis.

Nadya, H. (2012). Upaya Pencegahan Bahaya Kerusakan Dan Pemeliharaan Rekam Medis Di RSUD Tarakan. Skripsi. Ilmu Perpustakaan Universitas
Indonesia. Diakses pada Tanggal 13 Mei 2018.

Notoatmodjo, S. (2012). Metodologi Penelitian Kesehatan. Jakarta: Rineka Cipta.

Ni, Pramesti. (2014). Pemeliharaan Rekam Medis Inaktif Pasien Jiwa di RSJ grhasia DIY. http://etd.repository.ugm.ac.id/index.ph p?mod=penelitian_detail\&sub=Peneliti anDetail\&act=view\&typ=html\&buku_i $\mathrm{d}=71997$. Di akses pada tanggal 27 Mei 2018.

Novia, W. (2014). Tinjauan Pelaksanaan Pemeliharaan Dokumen Rekam Medis Di RSUD Sunan Kalijaga Demak. Jurnal Rekam Medis dan Informasi Kesehatan.http://eprints.dinus.ac.id/668 O/1/jurnal_13820. pdf. Diakses Pada Tanggal 28 april 2018.

Peraturan Menteri Kesehatan Republik Indonesia No.269/Menkes/Per/II/2008. Tentang Rekam Medis. Jakarta: Kemenkes RI.

Rustiyanto, E, Rahayu, WA. (2011). Manajemen Filing Dokumen Rekam Medis Dan Informasi Kesehatan. Yogyakarta: Politeknik Kesehatan Permata Indonesia.

World Health Organization. (2010). Tentang Rumah Sakit. Jakarta: WHO. 